\title{
РОЗРАХУНКИ 3 ПОКУПЦЯМИ: АСПЕКТИ ФОРМУВАННЯ ІНФОРМАЦІЙНОЇ БАЗИ УПРАВЛІНСЬКОГО ОБЛІКУ
}

\section{В. В. Жарнікова}

Київський національний торговельно-економічний університет

вул. Кіото, 19, м. Київ, 02000, Україна. E-mail: v.zharnikova@gmail.com

Визначено роль інформаційної бази обліку та управління розрахунками з покупцями в обліковій системі підприємств торгівлі та комплексі управління їх маркетинговою товарною політикою в сучасних умовах зростання конкуренції та діджиталізації торгівлі. Розроблено логічну схема розрахунків з покупцями за часовими формами. Ідентифіковано головні завдання організації обліку та управління розрахунками 3 покупцями в оптовій торгівлі, визначено основні завдання обліку та управління дебіторською заборгованістю на торговельних підприємствах. Удосконалено методику розрахунку реального прибутку торгового підприємства 3 урахуванням витрат на супроводження дебіторської заборгованості, збитків від несплачених рахунків, впливу курсових різниць. Побудовано схему впливу фінансових та комерційних складових на розрахунки з покупцями. Розроблено та охарактеризовано систему побудови інформаційної бази обліку та управління розрахунками 3 покупцями відповідно до етапів життєвого циклу торгового підприємства.

Ключові слова: облік; управлінський облік; торгові підприємства; оптова торгівля; дебіторська заборгованість.

\section{РАСЧЕТЫ С ПОКУПАТЕЛЯМИ: АСПЕКТЫ ФОРМИРОВАНИЯ ИНФОРМАЦИОННОЙ БАЗЫ УПРАВЛЕНЧЕСКОГО УЧЕТА}

\section{В. В. Жарникова}

Киевский национальный торгово-экономический университет

ул. Киото, 19, г. Киев, 02000, Украина. E-mail: v.zharnikova@gmail.com

Определена роль информационной базы учета и управления расчетами с покупателями в учетной системе предприятий торговли и комплексе управления их маркетинговой товарной политикой в современных условиях роста конкуренции и диджитализации торговли. Разработана логическая схема расчетов с покупателями с учетом временных форм. Идентифицированы главные задачи организации учета и управления расчетами с покупателями в торговле, определены основные задачи учета и управления дебиторской задолженностью на торговых предприятиях. Усовершенствована методика расчета реальной прибыли торгового предприятия с учетом затрат на сопровождение дебиторской задолженности, убытков от неоплаченных счетов, влияния курсовой разницы. Построена схема влияния финансовых и коммерческих составляющих на расчеты с покупателями. Разработана и охарактеризована система построения информационной базы учета и управления расчетами с покупателями в соответствии с этапами жизненного цикла торгового предприятия.

Ключевые слова: учет; управленческий учет; торговые предприятия; оптовая торговля; дебиторская задолженность.

АКТУАЛЬНІСТЬ РОБОТИ. Формування нових ринкових відносин зумовлює об'єктивну необхідність у нових підходах до обліку та управління розрахунками з покупцями та появі нових інформаційних потреб в управлінні оптовим торговим підприємством. Одним із способів реструктуризації бухгалтерського обліку є надання підприємствам сфери торгівлі інформаційних ресурсів необхідних для потреб управлінського обліку. Торгове підприємство самостійно розробляе систему управлінського обліку опираючись на обрану стратегію розвитку та свою бізнес-модель.

Метою діяльності кожного торгового підприємства $є$ отримання максимально можливого прибутку та підтримання фінансової стійкості. Більшість торгових підприємств не мають постійної й обгрунтованої політики прийняття рішень щодо управління розрахунками 3 покупцями, що спричиняє значні фінансові втрати або неможливість отримання частини прибутку. Таким чином, на сьогодні важливими завданнями для управлінського обліку в системі розрахунків з оптовими покупцями є:

формування аналітичних рахунків для кожного покупця та для кожного виду товару;
- використання різноманітних сучасних форм розрахунків з покупцями; оцінка якості та своєчасності оплат і розрахунків з покупцями;

- стан та динаміка виконання договорів 3 покупцями;

- $\quad$ визначення результатів від продажу товарів;

- $\quad$ оцінка впливу періодичності оплат покупців на податкове навантаження;

- оцінка фінансових результатів щодо кожного покупця;

- визначення ефективності різних обсягів продажу;

- формування управлінської та фінансової звітності.

Відсутність методів управлінського обліку в системі розрахунків 3 покупцями та досвід його практичного використання в діяльності торгових підприємств пов'язані з фактором невизначеності та відсутності інформаційної системи, яка могла б стати основою системи оперативного моніторингу бізнеспроцесів. Тільки за наявності актуальної та достовірної інформації про стан кожного бізнес-процесу, про динаміку документообігу можна сподіватися на підвищення ефективності [1]. 
В науковій літературі ведеться дискусія щодо специфіки обліку розрахунків 3 покупцями в системі управляння та похідного від нього - обліку дебіторської заборгованості. Ця дискусія активізується при формуванні концепцій та методологічних засад модернізації системи управління оптовим торговим підприємством. Долучаючись до неї, маємо можливість сформулювати власне бачення іiі сутності, окреслити аспекти, які $є$ основоположними при формуванні концептуальних засад сучасної системи обліку розрахунків з покупцями в сфері оптової торгівлі.

Більшість з існуючих наукових підходів до обліку розрахунків з покупцями зводиться до питань їх фінансового та управлінського обліку. Різниця між такими визначеннями полягає в тому, що науковці у більшій чи меншій мірі визначають розрахунки $з$ покупцями, як об'єкт одного чи іншого виду обліку. Можна також зустріти однобоке трактування розрахунків з покупцями, лише як облік дебіторської заборгованості.

Більшість авторів, які пишуть про питання управлінського обліку, не звертають уваги на платежі покупців. Наприклад, С.Ф. Голов вважає, що управлінський облік - це процес пошуку, зміни, накопичення, аналізу, підготовки, тлумачення, передачі інформації, яка використовується управлінською командою для планування, оцінки та інспекції на підприємстві та для забезпечення належного відповідального використання ресурсів [2].

Деяким вченим важко дати єдину відповідь про ефективність управлінського обліку в системі платежів $з$ покупцями на підприємствах. Так, для визначення ефективного ведення управлінського обліку в системі платежів $з$ покупцями, С.О. Кучеркова пропонує формувати внутрішню економічну звітність, яка забезпечить своєчасне отримання інформації про продану продукцію та платежі з покупцями за допомогою первинного обліку. Ця звітність може складатися 3 декількох підрозділів, а саме: виробництво продукції, продаж продукції та результати після продажу продукції [3]

Інший вчений Є.M. Заремба стверджує, що управлінський облік охоплює всі види бухгалтерської та не облікової інформації, яка використовується для негайного управління явищами та процесами щодо сегментів і центрів відповідальності, тому, на його думку, необхідно здійснювати оперативне обстеження й аналіз платежів з покупцями та грошовими потоками підприємства в управлінському обліку [4].

Науковець П.М. Гарасим, вважає, що належний контроль за платежами 3 покупцями може бути забезпечений лише за допомогою фінансового обліку. У той же час, облік розрахунків з покупцями, впливає на формування фінансових результатів, і досить надзвичайно ігнорувати його в управлінському обліку[5].

Сучасний управлінський облік на думку О.В. Фоміної полягає в: оптимізації організаційної та фінансової структури бізнесу; оптимізації бізнеспроцесів; впровадженні нових управлінських технологій; впровадженні процес-орієнтованого управ- ління затратами та крос-функціональних моделей управління бізнесом; включенні в обліковий процес усіх спеціалістів підприємства, які пов'язані $з$ документообігом, обліком, ланцюжком створення вартості продукту; підвищенні кваліфікації кадрів та їх мотивації в досягненні цільових значень ключових показників ефективності; впровадженні електронних засобів обробки даних і контролю за виконанням прийнятих рішень [6].

На думку Н.С. Марушко та Г.М. Валяник ефективність та оперативність управління підприємством і раціональне використання коштів залежить від вибору інформаційних систем. На сьогодні вітчизняний ринок інформаційних систем і технологій бухгалтерського обліку насичений пакетами прикладних програм, розроблених зарубіжними компаніями, проте спостерігається розвиток і вітчизняних технологій ведення обліку[7].

В своїх дослідженнях М.М. Нашкерська, Н.О. Литвиненко зазначають, що впровадження на підприємстві ефективної системи управління, в якій вагоме місце належить управлінню дебіторською заборгованістю може впливати на обсяг прибутку підприємства, його ліквідність і платоспроможність. У процесі управління дебіторською заборгованістю виникає проблема достовірності та повноти іiі інформаційного забезпечення. Відповідно, рівень ефективності управління грошовими потоками підприємства, зокрема дебіторською заборгованістю, визначається рівнем повноти і достовірності даних [8].

Не зважаючи на значну кількість досліджень у цьому напрямку, недостатньо висвітленим залишається актуальні на сьогодні питання, що пов'язані $з$ обгрунтуванням теоретико-методологічних підходів до формування інформаційної бази обліку та управління розрахунками з покупцями, враховуючи особливості системи управління, зростання конкуренції та диджиталізації в сфері торгівлі.

Метою статті є розкриття сутності та ролі обліку розрахунків з покупцями, а також надання рекомендацій у частині формування інформаційної бази для потреб обліку та управління розрахунками з покупцями в торгівлі відповідно до етапів життєвого циклу торгового підприємства.

МАТЕРІАЛ I РЕЗУЛЬТАТИ ДОСЛІДЖЕНЬ. Важливим елементом планування діяльності торгового підприємства є процес управління розрахунками 3 покупцями. Практика свідчить, що в більшості випадків діяльність 3 обліку та управління розрахунків з покупцями на підприємствах оптової торгівлі організована не дуже ефективно в результаті цього на підприємстві виникає неочікувана дебіторська заборгованість.

Найбільш гострими проблемами, пов'язаними 3 дебіторською заборгованістю є відсутність:

- принципів і системи кредитних умов для покупців;

системи планування і нормування дебіторської заборгованості;

- періодичного управління дебіторською заборгованістю;

підрозділу чи працівників із моніторингу дебіторської заборгованості; 
- інформаційної системи внутрішнього та зовнішнього документообігу;

- системи контролю й обміну інформацією про рівень дебіторської заборгованості;

- форм документів, з обліку, аналізу та інкасації дебіторської заборгованості.

Таким чином, більшість проблем, пов'язаних 3 дебіторською заборгованістю насамперед викликані відсутністю або недосконалістю інформаційної бази іiі обліку та управління.

Проте питання дебіторської заборгованості складають лише частину обліку та управління розрахун- ками $з$ покупцями. У даному випадку важливо побудувати таку інформаційну систему 3 обліку та управління розрахунками з покупцями, яка не створювала б ризиків виходу певних категорій покупців з числа активних учасників формування споживчого попиту в тому чи іншому сегменті оптової торгівлі через штучне створення умов розрахунків, за яких певна група покупців стає неприбутковою для торгового підприємства. Розрахунки з покупцями пропонується розглядати в контексті чотирьох часових форм (рис. 1)

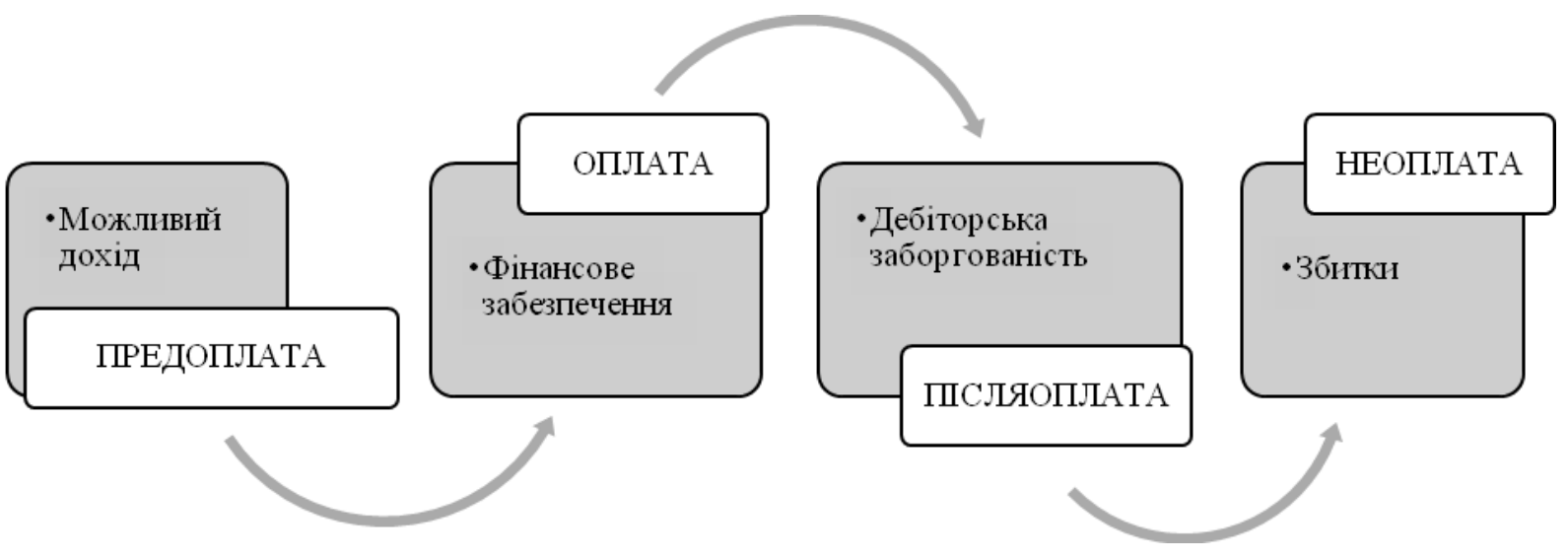

Рисунок 1 - Логічна схема розрахунків з покупцями за часовими формами (Джерело: розроблено автором за [9-12]. )

Слід зазначити, що розрахунки з покупцями на умовах передоплати зумовлені в більшості випадків пропозицією від продавця товарів-новинок, ексклюзивом, дефіцитом та наявністю вільних коштів у покупця. Розрахунки на умовах оплати в момент продажу товарів в основному виникають при наявності товару у продавця та коштів у покупця.

Найчастіше після оплата в розрахунках 3 покупцями пов'язана з намаганнями продавців або залучити нових клієнтів на цікавих умовах розрахунків або звільнити склади від залежалого товару та прискорити їх товарообіг. Несплата товарів покупцями в оптовій торгівлі найчастіше виникає на торгових підприємствах, де існують проблеми 3 обліку та ефективного управління відносинами 3 покупцями на умовах після оплати або взагалі відсутня інформаційна база про платоспроможність покупців.

Отже, кожна часова форма розрахунків 3 покупцями має свої особливі потреби до інформаційної бази. При цьому важливо чітко визначати завдання обліку та управління розрахунків із покупцями, обліку та управління дебіторської заборгованості.

До головних завдань організації обліку розрахунків із покупцями в оптовій торгівлі належать:

- нагляд за дотриманням форм розрахунків, що встановлені в договорах;

- правильне та своєчасне оформлення операцій з руху грошових коштів та розрахунків;
- контроль використання коштів у розрахунках за цільовим призначенням;

- вчасна звірка розрахунків із дебіторами щодо обліку очікуваної дебіторської заборгованості та запобігання неочікуваної.

До основних завдань управління розрахунками 3 покупцями належать:

- сегментація покупців за формами власності, товарною номенклатурою, територіальною приналежністю, обсягами товарообороту, інше;

- визначення системи лояльності для покупців та обрання методу розрахунку за товар;

- сприяння збільшенню обсягів продажу та зростанню прибутку шляхом надання комерційного кредиту;

- $\quad$ зростання конкурентоздатності шляхом відстрочення платежів;

- складання карти та графіку документообігу розрахункових документів;

- контроль передачі інформації із облікових реєстрів для їі відображення в звітності.

До головних завдань організації обліку дебіторської заборгованості належать:

- перевірка правильності та своєчасності документального оформлення операцій, що призводять до визнання та погашення (списання) дебіторської заборгованості; 
- забезпечення своєчасного і достовірного відображення на рахунках бухгалтерського обліку дебіторської заборгованості;

контроль за погашенням дебіторської заборгованості та списання дебіторської заборгованості, яку визнано безнадійною;

- визначення резерву сумнівних боргів відповідно до облікової політики підприємства;

- проведення інвентаризації дебіторської заборгованості, іiі оцінка в поточному обліку та на дату фінансової звітності;

- розкриття інформації про дебіторську заборгованість у фінансовій звітності.

До основних завдань управління дебіторською заборгованістю належать:

- розрахунок ступеня ризику несплати рахунків;

- розрахунок передбаченого розміру резерву сумнівних боргів;

- визначення облікових реєстрів щодо неочікуваної дебіторської заборгованості та надання інформації про неї керівництву для прийняття рішень;

- $\quad$ надання рекомендацій з приводу зменшення кількості фактично чи потенційно неплатоспроможних клієнтів.

Таким чином, завдання обліку розрахунків з покупцями в оптовій торгівлі декілька відрізняється від завдань обліку дебіторської заборгованості. Поперше, облік розрахунків 3 покупцями охоплює більше завдань, в тому числі облік очікуваної дебіторської заборгованості, а по-друге, облік розрахунків $з$ покупцями спрямований насамперед на попередження неочікуваної дебіторської заборгованості. В той же час, облік дебіторської заборгованості орієнтований на врахування вже існуючої сумнівної, безнадійної, простроченої заборгованості по розрахунках $з$ покупцями, яка була неочікуваною для торгового підприємства.

Відповідно до головних завдань обліку, основні завдання управління розрахунків з покупцями та управління дебіторською заборгованістю також відрізняються в оптовій торгівлі. Управління розрахунків з покупцями має більший спектр завдань та має більш превентивний характер системи управління, а управління дебіторською заборгованістю сконцентроване на окремому напрямку взаємовідносин та має девіантний характер системи управління.

Ефективність організації обліку та управління розрахунками з покупцями, у тому числі дебіторської заборгованості оцінюється розміром прибутку торгового підприємства. Зазвичай прибуток від реалізації товарів в оптовій торгівлі розраховується як різниця між виручкою (В) та витратами на закупівлю товарів (3Т) з додаванням комерційних витрат (КВ) й управлінських витрат (УВ).

Однак слід зазначити, що наявність дебіторської заборгованості впливає на виручку торгового підприємства, і має бути відображена при розрахунку реального прибутку, адже надання кредиту покупцям обходиться для торгового підприємства не безкоштовно, і його вартість треба враховувати.

Таким чином, що в даному випадку для торгових підприємств ефективність роботи 3 тим чи іншим покупцем доречно оцінювати за реальним прибутком. При розрахунку реального прибутку торгового підприємства від реалізації товарів доцільно обліковувати також витрати на фінансування (супроводження) дебіторської заборгованості (Д3), можливі збитки від несплачених рахунків (H3) та вплив курсових різниць $(K P)$ при реалізації валютного товару:

$$
P \Pi=B-3 T-К В-У В-Д 3-Н 3 \mp К Р
$$

де $Р П$ - реальний прибуток від реалізації товарів в оптовій торгівлі.

При цьому витрати на фінансування дебіторської заборгованості в залежності від обсягів торгівлі розраховуються виходячи з середньорічної (середньомісячної) дебіторській заборгованості помноженої на середню вартість залучення капіталу в рік (місяць) та розділеної на 100\%.

Принагідно слід зазначити, що збитки від несплати дебіторської заборгованості оцінюються за даними попереднього періоду, як відсоток непогашення дебіторської заборгованості розрахований за відповідний період: рік або місяць. Якщо торгове підприємство може спрогнозувати відсоток неповернення дебіторської заборгованості 3 достатнім ступенем точності то для достовірності управлінської звітності можуть бути створені резерви на покриття безнадійної дебіторської заборгованості.

Ефективна організація обліку та управління розрахунків 3 покупцями можлива лише при налагодженій інформаційній базі торгового підприємства, заснованій на тісній взаємодії фінансового та комерційного блоків.

Для того, щоб сформувати та регламентувати ефективну інформаційну базу розрахунків 3 покупцями, слід розглянути основні фактори впливу на систему розрахунків 3 покупцями 3 урахуванням фінансових та комерційних складових процесу.

До фінансових складових процесу розрахунків 3 покупцями в першу чергу відносять ціну товару, що реалізується, форми оплати та податки пов'язані 3 продажем товару.

До комерційних складових відносять зазвичай якісні характеристики товару, його наявність у торгового підприємства та доставка товару до пункту видачі покупцю.

Побудова інформаційної бази обліку та управління розрахунків з покупцями з огляду фінансових та комерційних складових повинна здійснюватися за шістьма основними напрямками, що уточнено на рис. 2, і передбачати безпосереднє застосування багатовимірного статистичного аналізу даних для обліку та управління. 

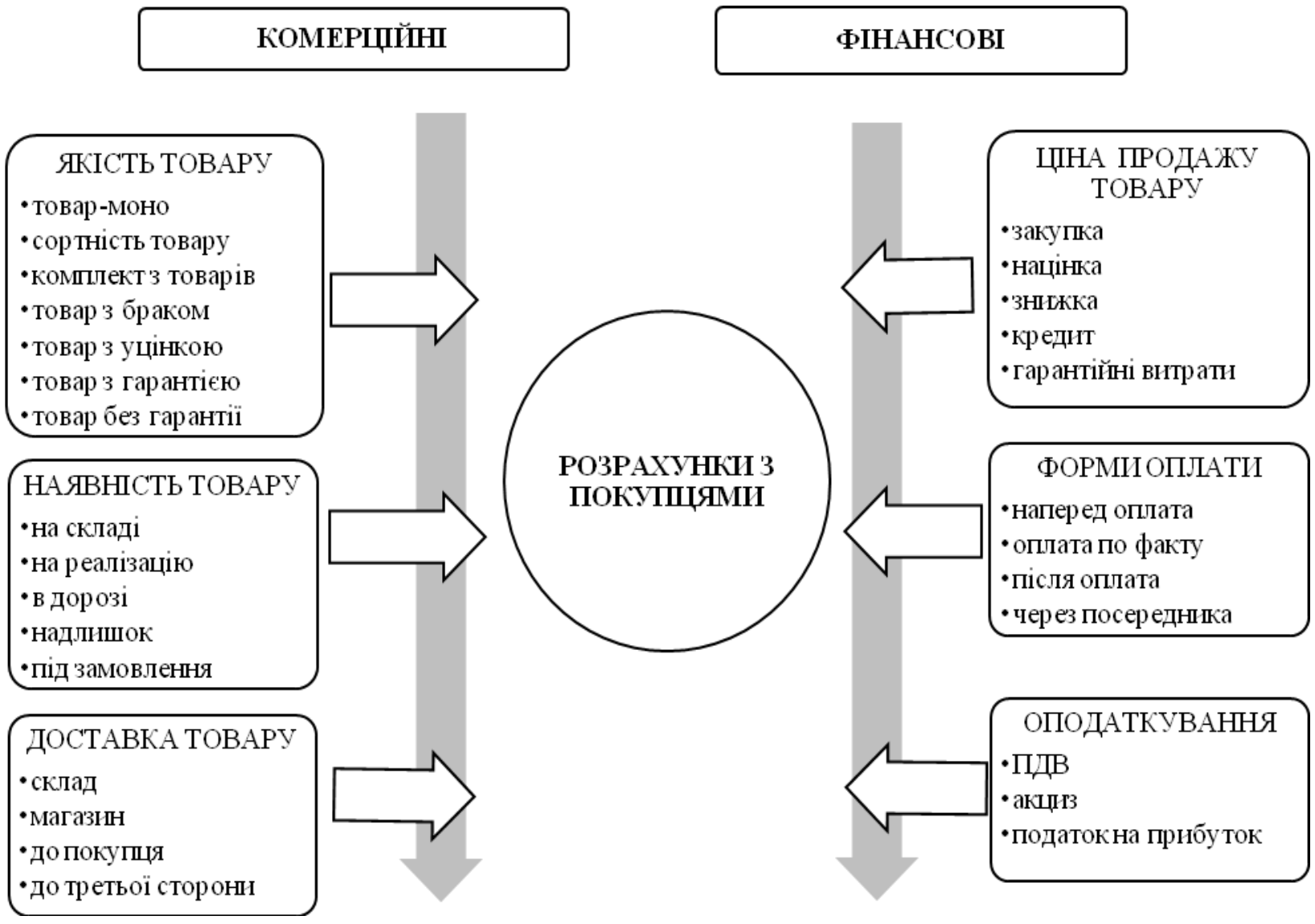

Рисунок 2 - Схема впливу фінансових та комерційних складових на розрахунки з покупцями (Джерело: розроблено автором за [9-14])

Інформаційна база обліку та управління розрахунків 3 покупцями 3 огляду комерційної складової включає данні щодо якості товару і його споживчих характеристик, наявності товару та доставки товару до точок видачі, що пов'язані між собою та впливають один на одного.

Якість товару формує попит на нього та впливає на його наявність та кількість, в свою чергу, наявність товару безпосередньо на складі торгового підприємства чи в дорозі або його надлишок чи дефіцит впливає на вибір точки доставки товару, починаючи від складу до третьої сторони, пов'язаної з покупцем. I навпаки, умови доставки товару можуть вплинути на якість товару та його наявність в точках видачі.

Таким чином, правильна організація обліку товару, його наявності та руху дозволяє ефективно керувати відносинами $з$ покупцями товару, пропонуючи їм товар відповідної якості та зручні умови його доставки, а також прискорювати товарооборот, зменшувати залишки неліквідного товару на складах, застосовуючи програми лояльності та акції щодо активізації збуту товару.

Крім того, що комерційні складові пов'язані між собою та впливають один на одного, вони є основою для правильного формування торговим підприємством ціни продажу товару для кожного оптового покупця.
Принагідно слід зазначити, що форми оплати покупцями товару суттєво впливають на реальний прибуток від реалізації товарів в оптовій торгівлі. При розрахунках 3 покупцями попередня оплата товарів або оплата їх повністю для продавця є найоптимальнішими. Проте для залучення нових покупців, для активізації існуючих клієнтів, для прискорення продажу неліквідного або залежалого товару торгові підприємства пропонують оплату товару в розстрочку або в кредит.

Отже, організація обліку розрахунків 3 покупцями повинна враховувати також данні про форми оплати за товар 3 інформаційної бази торгового підприємства. При оплаті товару в розстрочку або в кредит торговому підприємству для обліку та управління необхідні данні про строки оплати та середню вартість залучення коштів, а при оплаті наперед, інформація про дату отримання коштів, розміри дебіторської заборгованості за товар, процентний дохід від розміщення вільних коштів та графік розрахунків з постачальниками та бюджетом.

При розрахунках з покупцями окремого обліку та управління потребує оподаткування операцій 3 продажу товарів в оптовій торгівлі. Розрахунки 3 покупцями потребують інформаційного забезпечення щодо оподаткування податком на прибуток, акциз й особливо податок на додану вартість (ПДВ). При продажу товарів, що підлягають оподаткуван- 
ню ПДВ, у продавця виникає податкове зобов’язання, а у покупця податковий кредит.

У загальному випадку у продавця податкові зобов'язання з ПДВ виникають на дату першої події в операції: або відвантаження товарів чи фізичне переміщення товару від місця його знаходження у торговця до покупця або зарахування грошей на рахунок продавця, отримання передоплати на банківський рахунок чи в касу торгового підприємства.
Датою визнання податкового кредиту у покупця є дата «першої події»: або списання коштів із банківського рахунка платника ПДВ на оплату товарів або отримання платником ПДВ товарів.

Таким чином, підходи до формування інформаційної бази обліку та управління розрахунками 3 покупцями пропонується розглядати 3 позицій подій відвантаження товару та отримання грошей (рис. 3).

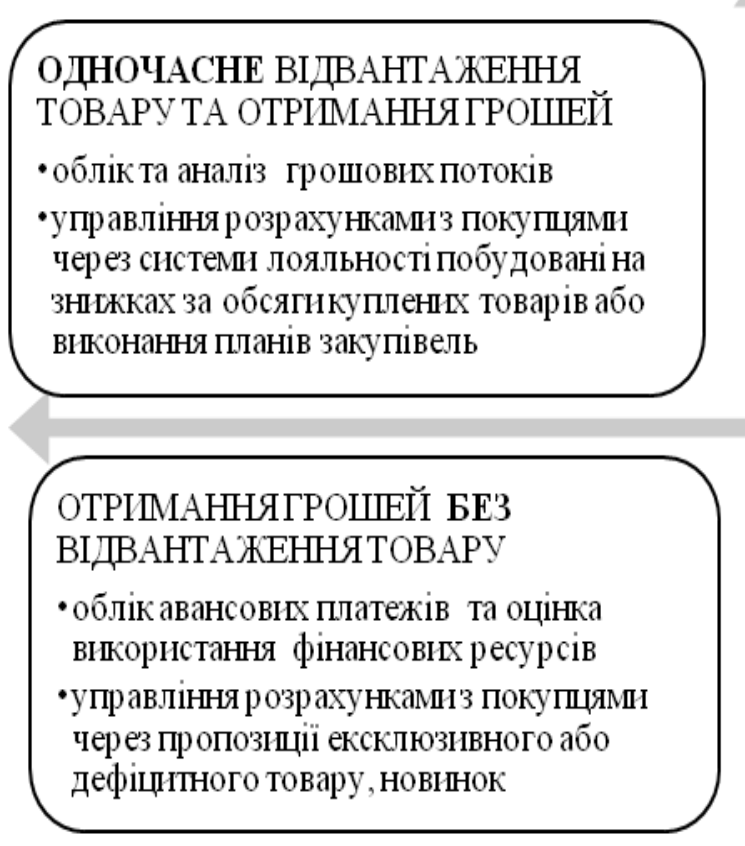

ВІДВАНТАЖЕННЯТОВАРУ БЕЗ

ОТРИМАННЯГРОШЕЙ

• облік та контроль дебіторської

заборгованності

•управління р озрахункамн'з покущцян

через стимулювання достр окового

погашення дебіторськоїзаборгованості

\section{ВІДСУТНЕ ВІДВАНТАЖЕННЯ ТОВАРУ ТА ОТРИМАННЯ ГРОШЕЙ}

\section{•плану вання та прогнозннй управлінській} облік

• 'залу чення нових покупців через акції та системн лояльності, зміна або розробка нової бізнес-стратегіі

Рисунок 3 - Система побудови інформаційної бази обліку та управління розрахунками з покупцями (Джерело: розроблено автором за [9-14])

Ефективна система організації обліку та управління розрахунками з покупцями базується на всебічному аналізі й оцінці облікової політики підприємства торгівлі, поточного стану управління розрахунками з покупцями та дебіторською заборгованістю на кожному етапі життєвої циклу торгового підприємства - становлення, зростання, насичення, зрілості та занепаду.

На стадії становлення торгового підприємства після формулювання підприємницької бізнес-ідеї мають бути визначені головні внутрішні вимоги щодо іï впровадження. Серед таких вимог важливу роль відіграє побудова інформаційної бази обліку та управління розрахунками 3 покупцями коли ще відсутнє будь-яке відвантаження товару та відповідно розрахунки з покупцями. Процес реалізації товарів, який є основним видом діяльності в торгівлі, вимагає проведення маркетингових досліджень, планування та прогнозування торговотехнологічного процесу, надання після продажного сервісу.

На стадії зростання торгове підприємство потребує збільшення обсягів фінансування, нарощення яких може відбуватися через посилення фінансового потенціалу за рахунок різних джерел, в т.ч. сплачених авансів і наперед оплати та формалізації документообігу та обліку через збільшення функціональних рівнів управління.

У міру насичення ринку товарами, появи нових конкурентів торгове підприємство досягає стадії зрілості. При розрахунках з покупцями відбувається одночасне відвантаження товару та отримання грошей, торгове підприємство за рахунок масштабних продажів збільшує обсяги операційного прибутку та одночасно формує лояльність певного кола покупців.

Оскільки серед основних факторів, які сприяють переходу торговельного підприємства на стадію відновлення, визначено відкритість зв'язків із зовнішнім середовищем через зростання розмірів розрахунків 3 покупцями в розстрочку та кредит, то особливої актуальності в зрілому віці підприємства торгівлі набуває посилення інформаційного та логістичного потенціалів.

Диференціація та ускладнення торгівельних відносин, які відбуваються на стадії зрілості торгового 
підприємства для запобігання занепаду та забезпечення відновлення підприємства торгівлі, потребують збільшення інформаційних потоків. Обробка зростаючих обсягів інформації і іiі різноманітність вимагають впровадження спеціалізованих інформаційних систем, починаючи від розробки відповідних програм залучення нових покупців через акції та системи лояльності до кардинальної зміни або розробки нової бізнес-стратегії.

Таким чином, на різних стадіях життєвого циклу перед торговельним підприємством постають різні завдання формування та розвитку обліку та управління розрахунків 3 покупцями із акцентуванням уваги на базових елементах його структури та поступовим посиленням управлінських функцій.

ВИСНОВКИ. Ефективний облік та управління розрахунками з покупцями в оптовій торгівлі, безперечно, впливає на стабільність зростання обсягів продажів товарів, ефективне використання резервів бази покупців, знижує ризик фінансових втрат й $є$ необхідною умовою успішної діяльності та підвищення конкурентоспроможності торгового підприємства.

При розгляді побудови облікової політики торгового підприємства визначається необхідність підпорядкування облікової інформації загальним інтересам інформаційної системи підприємства торгівлі, яка може бути представлена як сукупність потоків зовнішнього та внутрішнього нормативнометодичного забезпечення щодо формування організації та технології бухгалтерського обліку [15].

Використання економічної інформації в процесі обліку та аналізу на підприємствах оптової торгівлі може бути успішним тільки за умови створення комплексної системи дослідження та управління розрахунками 3 покупцями відповідно до обраної бізнес-стратегії торгового підприємства, що значно підвищить її ефективність.

За результатами досліджень щодо глобальної конкурентоспроможності країн у 2018 році на Всесвітньому економічному форумі, Україна має доволі конкурентоздатні роздрібні послуги та займає 57 позицію серед 140 країн, що досліджувались, та недостатні показники з розвитку інновацій, займаючи 112 позицію серед 140 країн [16].

Таким чином, розвиток інформаційних технологій, подальша діджиталізація форм розрахунків 3 покупцями, управління розрахунками через впровадження програм лояльності є необхідним фактором подальшого розвитку торгівлі та зумовлює необхідність у проведенні подальших досліджень за даною тематикою [10-11].

Висловлюю щиру подяку завідувачу кафедри обліку та оподаткування Киїського національного торговельно-економічного університету, доктору економічних наук, Фоміній Олені Володимирівні та професору кафедри обліку та оподаткування Киівського національного торговельно-економічного університету, відміннику освіти, доктору економічних наук, Бенько Миколі Миколайовичу за значний внесок в формування економічного мислення та сприяння щодо визначення наукової новизни тематики досліджень.

\section{ЛІТЕРАТУРА}

1. Шевченко О. О. та ін. Моделі оперативного моніторингу бізнес-процесів у підрозділах підприємств. Вісник Кременчуцького національного університету імені Михайла Остроградського. 2016. Вип. 6(101) ч. 2. С. 86-93.

2. Голов С. Ф. Бухгалтерський облік в Україні: аналіз стану та перспективи розвитку : монографія, К. : ЦУЛ, 2007. 522 с.

3. Кучеркова С. О. Покращення аналітичного обліку реалізації продукції та розрахунків з покупцями. Економічні науки: Облік $i$ фінанси. 2012. Вип. 9 (2). С. 223-228.

4. Заремба С. М. Обліково-аналітичне забезпечення інтегрованого бухгалтерського обліку грошових потоків підприємства. Економіка. Фінанси. Менеджмент: актуальні питання науки і практики. 2015. № 2. С. 46-52.

5. Гарасим П. М. Фінансовий, управлінський та податковий облік. Терноп. нац. екон. ун-т. ТНЕУ. 2003. 522 c.

6. Фоміна О. В. Вплив тенденцій в оптовій торгівлі на розвиток управлінського обліку. Вісник ОНУ ім. Мечнікова. 2014. Вип. 19 (2/6). С. 121-125.

7. Марушко Н. С., Воляник Г. М. Інформаційні системи ведення обліку: сучасний стан і тенденції розвитку. Науковий вісник НЛТУ України. 2015. Вип. 25(3). С. 370-377.

8. Нашкерська М. М. Облікове забезпечення управління поточною дебіторською заборгованістю Вісник Національного університету «Львівська політехніка». 2012. № 721. С. 186-191.

9. Жарнікова В. В. Учет расчетов с покупателями: систематизация взглядов и перспективы исследований. Свропейський науковий журнал Економічних та Фінансових інновацій. 2018. № 2. С. 4864.

10. Соболєва-Терещенко О. А., Жарнікова В. В. Теоретико-методологічні основи формування ефективних систем лояльності. Журнал Менеджер. 2017. Вип. 2(75). С. 82-91.

11. Соболєва-Терещенко О. А., Жарнікова В. В. Особливості бухгалтерського обліку розрахунків 3 покупцями в умовах застосування програм лояльності. Науковий вісник Ужгородського університету. Серія «Економіка». 2017. Вип. 2(50). С. 325-332.

12. Дворецкий Д. Ю., Жарникова В. В., Соболева-Терещенко Е. А. Особенности программ лояльности сегмента В2В на рынке высокотехнологичных товаров. Science and Education a New Dimension. Humanities and Social Sciences. 2019. Вип. VII(32). C. $14-18$.

13. Пацкова В. А., Сюткина М. В. Современные форматы торговли как приоритетная форма развития розничной торговли в условиях рыночной экономики. Математические методы и модели в 
управлении, экономике и соџуиологии. 2014. Вып. 8. C. 331-337.

14. Прушковский Л. В., Глазунова О. А. Значение оптовой торговли в системе хозяйственных отношений с розничной торговлей. Научный результат. Серия: Технология бизнеса и сервиса. 2016. Вып.1 (7). С. 37-43.

15. Касич А. О., Онищенко О. В. Еволюція наукових підходів до формування облікової політики підприємства. Вісник Кременчуцьккого національного університету імені Михайла Остроградського. 2013. Вип. 1(78). С. 172-180.

16. The Global Competitiveness Report 2018. [Електронний ресурс]. - Режим доступу: http://reports.weforum.org/global-competitivenessreport-2018/

\section{SETTLEMENTS WITH BUYERS: ASPECTS TO THE FORMATION OF THE MANAGEMENT ACCOUNTING INFORMATION BASE}

\section{Zharnikova}

Kiev National University of Trade and Economics

vul. Kyoto, 19, Kiev, 02000, Ukraine. E-mail: v.zharnikova@gmail.com

Purpose. The article examines the essence of the «settlements with buyers» term and its role and importance for trade enterprises of Ukraine in the modern conditions of increased competition and digitalization of trade is defined. The article aims to develop practical proposals and provide recommendations regarding account and management of settlements with buyers. Methodology. To achieve the purpose of the research, the system of general scientific and special methods were used as a theoretical and methodological base, namely: the dialectical method of scientific knowledge; system analysis methods; methods of analysis and synthesis; expert assessment method. Based on the review in various opinions of the researchers and the scientists, the justified the difference between "settlements with buyers" and "receivables" and importance this difference for accounting purposes are grounded. Results. Identified the base goals of the accounting and the management of settlement with buyers in trade and defined the main tasks of accounting and management of receivables in wholesale. The logical scheme of settlements with customers, taking into account temporary forms is developed, which included four forms of monetary relation between buyers and sellers. The analysis of current factors that influence on the creation of profit from settlement with buyers in trade is performed. The method for calculating the real profit in a wholesale has been improved, taking into account the costs of maintaining accounts receivable, losses from unpaid bills, and the effect of exchange differences. Originality. The factors affecting of settlement with buyers implementation, their features in the creating of information framework and developing of methodological ways to address the forming the accounting are considered. The scheme of influence of financial and commercial components on settlements with buyers has been built. . Practical value. It is found that, when considering the construction of accounting of settlement with buyers from the perspective of system approach its essence is determined by the need of accounting information about payments and shipment of goods. The system has been developed and characterized for constructing an information base for accounting and managing settlements with buyers in accordance with the stages of the life cycle of a trade enterprise. Conclusions are appropriate for the accounting in wholesales and making management decisions. Improving the information base in part of settlements with customers and develop loyalty programs are causes the research continuation in this direction. References 16, formula 1, figures 3.

Key words: accounting; management accounting; trade enterprises; wholesale; receivables.

\section{REFERENCES}

1. Shevchenko, A. A. (2016), "Modeli operatyvnoho monitorynhu biznes-protsesiv $v$ pidrozdilakh pidpryyemstv" [Models of operational monitoring of business processes in business units], Transactions of Kremenchuk Mykhailo Ostrohradskyi National University, No. 6 (101), pp. 86-93.

2. Golov, S. F. (2007), "Bukhhalters'kyy oblik v Ukrayini: analiz stanu ta perspektyvy rozvytku: monohrafiya" [Accounting in Ukraine: Analysis and Development Prospects: monograph], Moscow: TsUL, $522 \mathrm{pp}$.

3. Kucherkova, S. O. (2012), "Pokrashchennya analitychnoho obliku realizatsiyi produktsiyi ta rozrakhunkiv $z$ pokuptsyamy" [Improving the analytical accounting of sales of products and settlements with customers], Economics: Accounting and Finance, No. 9 (2), pp. 223-228.

4. Zaremba, Y. M. (2015), “Oblikovo-analitychne zabezpechennya intehrovanoho bukhhalters'koho obliku hroshovykh potokiv pidpryyemstva" [Accounting and analytical support for integrated accounting of cash flows of the company], Economy. Finance. Management: current issues of science and practice, No. 2, pp. 46-52.

5. Harasym, P. M. (2003), "Finansovyy, upravlins'kyy ta podatkovyy oblik: monohrafiya" [Financial, management and tax accounting: monograph], Ternopi: TNEU, 522 pp.

6. Fomina, O. V. (2014), "Vplyv tendentsiy $v$ optoviy torhivli na rozvytok upravlins'koho obliku" [Influence of trends in wholesale trade on the development of managerial accounting], Bulletin of the Mechnikov ONU, No. 19 (2/6), pp. 121-125.

7. Marushko, N. S., Volyanyk, H. M. (2015), "Informatsiyni systemy vedennya obliku: suchasnyy stan i tendentsiyi rozvytku" [Information accounting systems: current status and development trends], Scientific Bulletin of NLTU of Ukraine, No. 25 (3), pp. 370-377. 
8. Nashkers'ka, M. M. (2012), “Oblikove zabezpechennya upravlinnya potochnoyu debitors'koyu zaborhovanistyu" [Accounting support for the management of current receivables], Bulletin of the National University "Lviv Polytechnic", No. 721, pp. 186-191.

9. Zharnikova, V. V. (2018), "Uchet raschetov s pokupatelyamy: systematyzatsyya vz.hlyadov $y$ perspektyvy yssledovanyy" [Accounting of calculations with customers: systematization of views and prospects for research], European Journal of Economic and $\mathrm{Fi}$ nancial Innovation, No. 2, pp. 48-64.

10. Sobolieva-Tereshchenko, O. A., Zharnikova, V. V. (2017), "Teoretyko-metodolohichni osnovy formuvannya efektyvnykh system loyal'nosti" [Theoretical and methodological basis for the development of effective loyalty systems], Magazine Manager, No. 2(75), pp. 82-91.

11. Sobolieva-Tereshchenko, O. A., Zharnikova, V. V. (2017), “Osoblyvosti bukhhalters'koho obliku rozrakhunkiv z pokuptsyamy $v$ umovakh zastosuvannya prohram loyal'nosti" [Features of accounting settlements with customers in conditions of application of loyalty programs], Scientific bulletin of Uzhgorod University. Series "Economics", No. 2(50), pp. 325-332.

12. Dvoretskiy, D. Yu., Zharnikova, V. V., Sobolieva-Tereshchenko O. A. (2019), "Osobennosti programm loyal'nosti segmenta $B 2 B$ na rynke vysokotekhnologichnykh tovarov" [Features of loyalty programs B2B segment in the market of high-tech prod- ucts], Science and Education a New Dimension. Humanities and Social Sciences, No. VII (32), pp. 14-18.

13. Patskova, V. A., Syutkina, M. V. (2014), "Sovremennyye formaty torgovli kak prioritetnaya forma razvitiya roznichnoy torgovli $v$ usloviyakh rynochnoy ekonomiki" [Modern trade formats as a priority form of retail development in a market economy], Mathematical methods and models in management, economics and sociology, No. 8, pp. 331-337.

14. Prushkovsky, L. V., Glazunova, O. A. (2016), "Znacheniye optovoy torgovli $v$ sisteme khozyaystvennykh otnosheniy s roznichnoy torgovley" [The importance of wholesale trade in the system of economic relations with retail trade], Research result. Issue: Technologies of business and service series, No. 1(7), pp. 37-43.

15. Kasych, A. O., Onyshchenko, O. V. (2013), "Evolyutsiya naukovykh pidkhodiv do formuvannya oblikovoyi polityky pidpryyemstva" [Evolution of scientific approaches to the formation of the accounting policy of an enterprise], Transactions of Kremenchuk Mykhailo Ostrohradskyi National University, No. 1(78), pp. 172-180.

16. The Global Competitiveness Report 2018, available at: http://reports.weforum.org/globalcompetitiveness-report-2018/ (May 10, 2019).

Стаття надійшла 05.06.2019. 